\title{
TO AGREE OR NOT TO AGREE? ENGLISH ADJECTIVES IN ESTONIAN-ENGLISH BILINGUAL BLOGS AND VLOGS
}

\author{
Helin Kask \\ Tallinn University
}

\begin{abstract}
The article focuses on the agreement (in case and number) of English adjectives used with Estonian nouns in noun phrases (Eng ADJ + EST N) in Estonian blogs and vlogs. According to the Matrix Language Frame model (MLF), one would expect English adjective stems to take on Estonian inflections, but this is not always the case. The data comes from fashion and lifestyle blogs and vlogs that have Estonian as the main language and contain English language material to various degrees. Altogether, 84 noun phrases were analysed: in 35 instances the adjective agreed with the noun and in 46 instances it did not; in 3 instances the agreement was complicated to determine. The analysis showed that English adjectives that have a sound structure similar to Estonian adjectives as a rule agree with Estonian nouns. Factors that may lead to non-agreement are stem alternation, differences in writing and pronunciation, and personal preferences.
\end{abstract}

Keywords: adjectives, agreement, language contacts, blogs, vlogs, English, Estonian

DOI: https://doi.org/10.12697/jeful.2019.10.2.06

\section{Introduction}

The aim of this article is to investigate agreement and non-agreement in the noun phrase (NP) of structure Eng ADJ + Est N and to determine what factors may cause non-agreement. Estonian is typologically different from English: it has rich inflectional morphology and a highly developed case system (14 grammatical cases), whereby adjectives agree with nouns in case and number (in some instances, in number only). According to Matrix Language Frame model (MLF) (MyersScotton 1997), in a bilingual clause there is a matrix language, i.e. a base language, which is dominant and sets the grammatical frame. Embedded language refers to other languages in the sentence. Lexical morphemes (so called "islands") from an embedded language are inserted into the matrix language, the premise is that the embedded language content 
morphemes take on matrix language inflections. In my data, the main language in blogs and vlogs is Estonian, thus English is the "embedded language" and Estonian the "matrix language", so in NPs English stems are expected to take on Estonian inflections, my data shows this is far more complex: it happens in many instances, but not all (occasionally English adjectives remain uninflected).

In Estonian, adjectives can also be used as an adverbial in essive or in translative (for example, meik teeb mind ilusamaks 'make-up makes me prettier') and as a predicative (for example, seelik on sinine 'skirt is blue'). Predicatives were not analysed, because in these cases the adjective is used in the nominative, meaning the adjective does not need any case marking (if the morphosyntax requires it, a predicative could be in the plural, but this kind of example did not appear in my data).

Due to globalization, contacts between English and Estonian are common. Language contact is about the way in which languages in contact influence one another (Matras 2012b: 66). According to the usage-based approach to language contacts (Backus 2015), mental representation is based directly on usage and structure factors do not only determine what happens in language contacts. Meaning, frequency, cognitive aspects, such as bilingual perception, and entrenchment also play a role. According to Verschik (2019), monological asynchronous genres (like blogs and vlogs) provide a window into these aspects in individual language use and multilingual repertoire. The data for this study comes from Estonian fashion and lifestyle blogs and vlogs, which have proved to be a setting with much English-Estonian language contact (Kask 2016, Ratt 2017, Roosileht 2013, and Verschik and Kask 2019). This study is qualitative. As noted by Zenner, Backus and Winter-Froemel (2019: 7), contact linguistics pushes up against barriers of data collection and usually corpora are not big enough and representative enough to be suitable for sophisticated quantitative analyses. Moreover, Verschik (2019) suggests that contact linguistics should focus on individuals in addition to multilingual communities as the change in use starts from a multilingual individual (Backus 2012, and Matras 2009, 2012a).

The article is organised as follows: firstly, the sociolinguistic background is described; then, adjectives and their (non-)agreement in English and in Estonian is discussed. After that the data and informants are described. This is followed by a qualitative analysis of the data; distinctive or unique examples are presented and analysed. Finally, conclusions are drawn. 


\section{Sociolinguistic background of Estonia}

After Estonia regained its independence in 1991 English-Estonian language contact intensified and several English loans were and continued to be established in Estonian (Leemets 2002: 41). Over the intervening years the importance of English has increased; it is considered as one of the principal lingua franca in the world. $38 \%$ of Estonians claim ability to speak English, with the figure being higher among the younger generation (Kruusvall 2015: 77). According to Eurobarometer, $97 \%$ of Estonian students had learned English as part of their general studies. Also, 64\% of secondary school age Estonian students claimed their level in English was fluent or excellent (Ehala 2014: 195, based on MeeMa 2014). It is not, therefore, surprising that Estonian students consider English as the most important subject at school (Tammemägi and Ehala 2012: 249). It is also very common for younger people to be exposed to English-language entertainment and popular culture and use English in social networking online on a daily basis. The same occurs world-wide. More and more studies focusing on the pragmatic and social aspects of borrowing from English (see Fiedler 2017, Peterson and Vaattovaara 2014, and Peterson 2017) are being published, suggesting that borrowing from English is not only about borrowing of highly specific English lexical items but also about pragmatic models, for example, incorporating norms of interaction and discourse patterns.

Due to globalization, there is a need to describe many new concepts; usually they are first coined in English. Backus (2001) has suggested that words with specific meaning (e.g. terms, content words describing a certain domain, specific adjectives, etc.) are primary candidates for insertions (stems from other languages). Such English words and expressions are used in Estonian. The use of English lexical borrowings is very common in fields that develop and change rapidly, e.g. information technology. Contact with English is, therefore, both extensive (English appears in different types of text and oral communication) and intensive (there are instances of both online and offline Estonian-toEstonian communication in English, which give witness to the internalisation of English). English is no longer just a prestigious lingua franca, a neutral international language, but a part of individual repertoire (Blommaert and Backus 2011). 
So far, research on the impact of English on Estonian and EnglishEstonian language contacts has been limited to studies on conventionalised lexical borrowings in Standard Estonian (Leemets 2003) and a handful of MA theses written within the scope of one or another contact linguistics theoretical frameworks and exploring the impact of English in internet communication (Igav 2013, Ratt 2017, Roosileht 2013, Vaba 2010, and Voolaid 2017). There is a small body of recent articles discussing the structure and norms of English-Estonian language contacts in blogs (Verschik and Kask 2019) and applying a combination of a cognitive approach and code-copying framework to the EnglishEstonian multilingual repertoire (Verschik 2019).

The adjectives discussed in this article are of two types, namely those that have an Estonian translation equivalent and those that do not (highly specific). These highly specific adjectives can be colour names and styles and may even contain a metaphor (e.g. the colour magenta is named after the uniforms worn in the Battle of Magenta in 1859). Likewise, some adjectives are common among certain groups, e.g. the adjectives nude and casual are peculiar to beauty bloggers/vloggers. Studies about English-Estonian language contact by Igav (2013), Roosileht (2013) and Vaba (2010) confirm that English adjectives are often used to signal attitudes, they convey strong emotions and are prominent on the pragmatic level. They are also more colourful and add expressiveness to the text (Kask 2016). For example, adjectives like badass and crappy are both colloquial adjectives, that convey strong emotions and may be a part of the blogger's/vlogger's personal style. Thus, the reason for their usage is pragmatic and not purely semantic, as they are prominent on the pragmatic level (Backus and Verschik 2012: 146-147).

In the next section, I will discuss Estonian adjective-noun agreement and provide an overview on literature describing agreement in contact situations.

\section{Theoretical background}

In this section, agreement patterns in Estonian are discussed; and, examples of how language contacts can cause changes in an agreement system are presented. Estonian is a Uralic language, belonging to the Finnic branch. It is a predominantly an agglutinative language with 
fusional tendencies (Erelt 2007: 130). English is an Indo-European (Germanic) analytic language. Mostly, in agglutinative languages all declensional items have the same set of endings. In Estonian, words are divided into declensional classes based on phonological features (the number of stem syllables, phonological quantity (Q1, Q2, Q3) and presence/lack of stem alternation, etc.).

In Estonian, declensional class model words are provided to illustrate how to decline words with similar structure and how markers are added. Model words are especially useful in case of quality and quantity alternation, as they show how the quality and quantity of the alternates. For example, adjective suur 'big' belongs to the $13^{\text {nh }}$ declensional class ${ }^{1}$ and there is quantity alternation: nominative suur (strong grade, Q3) : genitive suure (weak grade, Q2) : partitive suurt (strong grade, Q3). Adjective halb 'bad' belongs to the 22nd declensional class and there is quality alternation: nominative halb (strong grade with $b$ ) : genitive halva (weak grade with $v$ ) : partitive halba (strong grade with $b$ ).

So, if the adjective and the noun belong to the same declensional class, they are declined the same way and they share the same markers (Peebo 1997). For example, the adjective ilus 'beautiful' and noun seelik 'skirt' both belong to the same declensional class (the stem has three syllables, no alternations in the stem) and receive the same markers, ilusa-te-s seeliku-te-s 'in beautiful skirts' (beautiful-PL-INE skirt-PL-INE).

Thus, the model word represents a certain declensional pattern, it shows how the stem alternates and what are the plural and case markers. In Estonian grammars model words for declinable words are usually nouns and although words in the same declension share the same markers, the stem vowel may differ. To help explain agreement, in this article prototype words are used. These are like model words, but these are narrowed down and chosen to have a similar sound structure as the English adjectives analysed. For example, adjectives analysed in section 5.2 (fancy, crazy etc.) would phonetically fit into the 16th declensional class where the model word is pere 'family' (NOM pere : GEN pere: PART peret). From this declensional class an adjective tubli 'diligent, appropriate' was chosen as a prototype word to help explain agreement as it has a sound structure similar to the adjectives fancy, crazy etc.

1 Hereafter, the classification of declensional classes is based on dictionary of Estonian “Eesti õigekeelsussõnaraamat ÕS 2018" (ÕS 2018). 
In both languages, adjective in the NP precedes the noun it modifies. In Modern English, adjectives are not declined, and do not agree in form with the noun they modify, unlike in most other IndoEuropean languages. On the other hand, in Estonian, the adjective takes on the same number and case as the noun. For example, in Estonian ilusa-te-st kleiti-de-st 'about beautiful dresses' (beautiful-PL-ELA dress-PL-ELA), both the adjective and the noun are in the elative plural, but in English about beautiful dresses (beautiful.sG dress.PL) the adjective remains in the singular.

However, in Estonian, if a noun is in one of the following cases (terminative, essive, abessive, or comitative), the adjective is present as a stem (technically, the genitive stem, from which all oblique cases, except the partitive, are formed) and is marked for number only, e.g. ilusa-te kleiti-de-ga 'with beautiful dresses' (beautiful-PL.GEN dress-PL-COM). In Table 1, agreement in Estonian is presented based on adjective ilus ('beautiful, pretty') and noun kleit ('dress').

Table 1. Agreement in Estonian cases

\begin{tabular}{lllll}
\hline Case & \multicolumn{3}{c}{ Singular } & Plural \\
\cline { 2 - 5 } & Adjective & Noun & Adjective & Noun \\
\hline Nominative & ilus & kleit & ilusa-d & kleidi-d \\
Genitive & ilusa & kleidi & ilusa-te & kleiti-de \\
Partitive & ilusa-t & kleiti & ilusa-id & kleiti-sid/kleite \\
Illative & ilusa-sse & kleidi-sse / kleiti & ilusa-te-sse & kleiti-de-sse \\
Inessive & ilusa-s & kleidi-s & ilusa-te-s & kleiti-de-s \\
Elative & ilusa-st & kleidi-st & ilusa-te-st & kleiti-de-st \\
Allative & ilusa-le & kleidi-le & ilusa-te-le & kleiti-de-le \\
Adessive & ilusa-l & kleidi-l & ilusa-te-l & kleiti-de-l \\
Ablative & ilusa-lt & kleidi-lt & ilusa-te-lt & kleiti-de-lt \\
Translative & ilusa-ks & kleidi-ks & ilusa-te-ks & kleiti-de-ks \\
Terminative & ilusa & kleidi-ni & ilusa-te & kleiti-de-ni \\
Essive & ilusa & kleidi-na & ilusa-te & kleiti-de-na \\
Abessive & ilusa & kleidi-ta & ilusa-te & kleiti-de-ta \\
Comitative & ilusa & kleidi-ga & ilusa-te & kleiti-de-ga \\
\hline
\end{tabular}


There is a small group of adjectives in Estonian that do not agree with a noun. These are called indeclinable adjectives that do not allow inflection. Although these adjectives are used as attributes and describe the noun, they do not agree with the noun in number or case; according to prescriptive grammar they lack comparative forms. These adjectives are mostly rooted forms, e.g. katoliku kirik 'Catholic Church', kulla mees 'good person'.

Relatively recently a discussion on adjectival (non)agreement was held in Estonian linguistics. Viitso (2007) discusses whether the presence of indeclinable adjectives can mean the involution (return) of a language from declinable adjectives to indeclinable. In contrast to this, Erelt (2008: 442) suggests that indeclinable adjectives will rather undergo change and eventually take on agreement. However, this discussion is about historical developments in Estonian and does not concern ongoing contact-induced language change. Still, in language contact cases the agreement system may change.

Adjectival agreement in Finnic languages shows there is a shift towards a fusional type (Sutrop 1997: 205-206). Moreover, Estonian has a growing tendency towards isolation (Metslang 1994). That would imply that non-declinable or partially declinable adjectives in Estonian are not likely to disappear. This is why adjective-noun agreement is dynamic.

To my knowledge, similar research about integrating English adjectives concerning other Finnic languages has not been carried out. A study by Halmari (1997) focuses on American Finnish, and adjectivenoun agreement is mentioned briefly. Besides, the sociolinguistic setting is quite dissimilar, as she explores Finnish-English language contacts in Finnish immigrants to the USA, and the English language input is quantitatively and qualitatively different.

Matras (2009: 188) found that in contact situations, when the syntactic position requires it, adjectives are usually integrated according to the rules of the matrix language. For example, in Hebrew and German, borrowed adjectives function as native words and they take on the markers of the matrix language. However, there are examples of borrowed adjectives that do not take on agreement inflection, e.g. Arabic-derived adjectives in modern Persian and Kurdish. The reason might be that adjectives must first undergo either derivational modifications or be assigned to a specific inflectional class. For example, 
in Hebrew, all adjectives are first assigned gender and number agreement markers (Matras 2009: 188-189). This implies that agreement depends on structural factors (compatibility with adjective types in the matrix language).

Quite differently, Stolz (2015: 272) notes that in language contacts, agreement systems are often eliminated, as they are associated with redundancy. For example, Armenian has long been under the influence of Turkic languages and due to this has undergone several changes. This has resulted in the loss of agreement of polysyllabic pre-nominal adjectives, although monosyllabic adjectives in the same position tend to agree (Stolz 2015: 274-276). Still, Stolz also draws examples of languages where agreement arises from language contact, e.g. in the Balto-Finnic branch due to contact with the neighbouring Indo-European languages. Another example is the Spanish elements in Yucatec Maya (Stolz 2015: 286-288).

However, Stolz (2015) discusses discontinuous changes as opposed to ongoing ones, in the terms of Tsitsipis (1998), focusing on contactinduced changes of the agreement system in languages. On the contrary, the current article focuses on ongoing change and concerns only English loan adjectives. It is unlikely that contacts with English will cause the loss of the adjective-noun agreement system in Estonian in the short term. Rather the question is how and whether English loan adjectives will adjust to the Estonian agreement system. As the contact situation is so nascent, it is too early to make definitive claims, potentially it could go either way.

Johanson (2002: 109) explains that in language contact situations loss of agreement marking is fairly frequent and marking can be eliminated without compensation, as agreement is semantically redundant (the same argument as in Stolz 2015) and the grammatical information is conveyed by the noun. Due to this, it might be assumed that the loss of agreement marking is affected by language contact.

Also, there is some evidence in the literature that morphosyntactic integration is a matter of personal preference (Zabrodskaja and Verschik 2014: 470). The same was noted by Zabrodskaja when investigating morphological integration of Estonian nouns into the Russian matrix. She found that integration depends on structural factors only to a certain extent. According to Zabrdoskaja (2009: 368), integration depends rather on individual preferences, types of discourse, oral or written 
modality etc., the noun fitting into any of the Russian noun declension classes was less important.

Integration as a matter of personal preference is illustrated by examples 1 and 2: one vlogger integrates the adjective basic and the other one does not. Hereafter, NP is presented in bold.

(1) V2

3 basicu-t asja, mida su-l vaja

3 basic-PART thing.PART that you-ADE need

' 3 basic things that you need'

(2) V4

mina looda-n, et te jätka-te oma basic eluviisi-ga I hope-1sG that you continue-2PL own.GeN basic lifestyle-COM 'I hope that you continue with your basic lifestyle'

Another reason for non-agreement is that multilinguals do not operate with separate monolingual grammars (see Cook 2016). For instance, Leisiö (2001) notes that bilinguals perceive "foreign" elements and treat them differently as they do not need to apply full morphosyntactic integration. Zabrodskaja and Verschik (2014) found that for bilinguals, borrowed nouns do not have to be grammatically "wellformed" or integrated for understanding. A bilingual does not need the same kind of mechanisms of integration as a monolingual does, because a bilingual understands how both grammars work and can have a combined system where both grammars are active simultaneously, rather than the monolingual grammar being in isolation. It all comes down to multicompetence, which is defined as "the overall system of a mind or a community that uses more than one language" (Cook 2016: 3). The idea is that a multilingual person has greater knowledge and resources to use than a monolingual person (Cook 2016).

To sum up, in the course of language contact, a loss of agreement marking is not rare. The reasons behind the non-integration of loan adjectives might be that they are incompatible with the inflectional system of the matrix language; loan adjectives might be perceived as indeclinable and agreement is semantically and grammatically redundant. 


\section{Data and informants}

Due to the rise of computer-mediated communication, there are new text-based genres that present interesting multilingual communication practices (Thurlow, Lengel and Tomic 2004: 31). One of them is the blog, a web journal that consists of posts in chronological order. A blog post can vary in length from that of a short note to an essay. Posts are usually written according to a schedule, for example, either every day or once a week. Blog posts are asynchronous monologues: the posts can be read days or even years after they are written. Usually, a blog is run by one person alone and reflects the personality of the blogger (Crystal 2007: 15, 240).

Vlogs (video blogs) are a form of blogging. In this genre, people record their opinions and feelings in a video and share it with their audience. The most popular platform for this is YouTube (TeijeiroMosquera et al. 2015). Vlogging has become more popular as video production tools (e.g., phones with cameras, webcams, editing software) have become more widely available. The richness of expression of this medium makes this genre popular: overall composition, nonverbal behaviour, background etc. play a role creating a unique vlogging style (Aran, Biel and Gatica-Perez 2014). Compared to blogging, this is a new type of social interaction which is more remote and contains even more different ways to express oneself.

Blogs are a great source for analysing language use as the language presented in displays the process of writing in its naked, unedited form (Crystal 2007: 15-16). In some cases, the language use in vlogs could be very immediate as the editing process is more time-consuming and filming new parts of a video to rephrase a sentence is troublesome. Both in blogs and vlogs, people are far more creative, exploring different expressions and using fresh combinations of elements as the Internet is fluid, and a blogger/vlogger can manifest her/his own language use. Because of this it is possible to explore multilingual language use and contact phenomena. Moreover, in blogs some features that do not appear in oral use are exposed, for example, orthography. Therefore, blogs and vlogs are a good resource for the study of language use as they contain the material in a naked form (see Igav 2013, Ratt 2017, Roosileht 2013, Vaba 2010, and Verschik 2016). 
Two sets of data were analysed. First, the written data from blogs. The data comprise blog entries from 45 fashion, beauty and lifestyle blogs. According to a study carried out by IPREX (Kulper 2015), fashion is one of the major topics in Estonian blogs. The majority of Estonian fashion bloggers write in Estonian (albeit with lexical elements from English), although some blogs have many or all entries in two languages (parallel texts that present more or less the same information). However, the text that appears second is not a precise translation of the first.

In the current article, a blogger/vlogger is considered multilingual if $\mathrm{s} / \mathrm{he}$ has the ability to communicate in more than one language in everyday life, the proficiency may range from minimal proficiency to full literacy (Cenoz 2013: 5-6). As all the informants use English frequently in their posts, they are considered multilingual. The only restriction to include the blog/vlog post in my data was that it had to contain at least one lexical element of English. However, in my data, lexical elements from English are used quite often: on average there were 15 English words or sentences in a blog post or 34 in a vlog post.

Likely due to the topic, most bloggers in the present study are female, except for two males who keep one blog together. At the time of blogging, the 48 bloggers were 19-30 years old and all resided in Estonia, mostly in Tallinn, while a small minority lived in other towns. They all have revealed at least their first name. The blog posts were written between 2012-2017. Today, some blogs have either been deleted or are accessible by invited readers only. Every blog entry was saved as a separate file in the Notepad++ program, and language contact phenomena were manually annotated. The data form a corpus that consists of 750 files and 275,263 words in total. The frequency of posting varied: some bloggers wrote every day, some once or twice a week. On average, there were 367 words per blog post, although this varied as well: some posts consisted of just a few sentences and some were up to 1,000 words long.

The second set of data comes from vlogs (oral speech). The data comprise entries from 6 fashion, beauty and lifestyle vlogs. All 6 vloggers were 15-29 years old and they all resided in Estonia, mostly in Tallinn, and have revealed at least their first name. Mostly, vloggers upload a video every week. The vlogs were all filmed in 2018. Every 
vlog post was listened to via YouTube and sentences that contained language contact phenomena were transcribed and manually annotated and saved as a separate file in the Notepad ++ program. The data forms a corpus that consists of 36 files with 6 hours 54 minutes 51 seconds of footage (approximately 48,000 words in total). Later, a full-automatic web-based speech recognition program was used to transcribe the videos. The program is meant for monolingual Estonian, a word error rate is $8.1 \%$ (Alumäe, Tilk and Asadullah 2019). When transcribing vlogs, English words were replaced with Estonian words that are pronounced similarly, so the error rate might be higher. According to the full-automatic web-based speech recognition program, on average, there are 1,333 words per video.

For this study, all the posts were manually analysed to identify the examples where an English adjective was used with an Estonian noun. Examples where syntactic position requires the adjective to be in the nominative were not taken into account. Examples came from 26 informants out of 54 (see Table 2).

Table 2. The number of examples in blogs and vlogs

\begin{tabular}{lccccc}
\hline & $\begin{array}{c}\text { Number of } \\
\text { informants }\end{array}$ & NPs & ADJ agrees & $\begin{array}{c}\text { ADJ does } \\
\text { not agree }\end{array}$ & $\begin{array}{c}\text { Agreement } \\
\text { not certain }\end{array}$ \\
\hline Blogs & 21 & 65 & 25 & 37 & 3 \\
Vlogs & 5 & 19 & 10 & 9 & 0 \\
Total & 26 & 84 & 35 & 46 & 3 \\
\hline
\end{tabular}

All together there were 84 examples from 26 informants: in 35 examples the English adjective agreed with the Estonian noun, in 46 examples the adjective did not agree with the noun and in 3 examples the agreement was impossible to determine. In blogs, there were 65 examples from 21 informants. In 25 instances the adjective agreed with the noun, and in 37 instances it did not, while in 3 instances due to the morphosyntactic position agreement could not be definitively assessed. In vlogs, there were 19 examples from 5 informants. In 10 instances the adjective agreed with the noun and in 9 instances it did not. All informants were given a code which consisted of the letter B in case of bloggers and the letter $\mathrm{V}$ in case of vloggers and a number based on the alphabetical order of the informants. For example, code V2 shows that 
the example comes from the vlogger who is listed second in the alphabetical order of vloggers.

As mentioned in section 3, Zabrodskaja (2009: 368) suggests that one of the factors that affects agreement is personal preference. To illustrate that, table 3 presents how many bloggers and vloggers always or sometimes integrated the adjective.

Table 3. The preference for agreement among bloggers and vloggers

\begin{tabular}{lccc}
\hline & $\begin{array}{c}\text { Always integrated } \\
\text { the adjective }\end{array}$ & $\begin{array}{c}\text { Never integrated } \\
\text { the adjective }\end{array}$ & $\begin{array}{c}\text { Sometimes integrated, } \\
\text { sometimes not }\end{array}$ \\
\hline Bloggers & 7 & 7 & 7 \\
Vloggers & 3 & 0 & 2 \\
Total & 10 & 7 & 9 \\
\hline
\end{tabular}

In my data, all 5 vloggers always or sometimes integrated the adjective (respectively 3 and 2 vloggers). Among bloggers 14 bloggers out of 21 always or sometimes used agreement while 7 bloggers never integrated the adjective. This shows that 19 informants out of 26 know how to use Estonian agreement system on English adjectives.

In conclusion, this study is qualitative because it is based on relatively small corpora, as there is not much data containing EnglishEstonian language contacts. The problem of small corpora is inherent to contact linguistics (Zenner et al. 2019). There are a few morphological and phonotactical aspects that may affect the integration of English adjectives. These are discussed in the following sections.

\section{Total morphological integration of an English adjective into the Estonian matrix}

According to Matras (2009: 188), in terms of agreement, adjectives are similar to nouns, meaning they tend to adopt the agreement morphology of the recipient language. Due to this, when adjectives are used in the syntactic position of the attribute they are integrated. As mentioned above, the MLF model suggests that the matrix language provides the morphosyntactic frame (Myers-Scotton 1997), meaning that English adjectives should receive Estonian case and number assignment. 
In Table 4, English adjectives that agreed with the Estonian nouns are presented. In my data, adjectives were integrated into Estonian 35 times out of 84 ( 25 instances in blogs and 10 instances in vlogs). The adjectives behave syntactically as if they were Estonian adjectives: they are used in the same case and number as the Estonian noun.

Table 4. Adjectives that were morphosyntactically integrated

\begin{tabular}{lc}
\hline English adjective & Number of tokens \\
\hline cool & 13 \\
fancy & 5 \\
basic & 3 \\
chill & 3 \\
deep & 2 \\
clean & 1 \\
crap & 1 \\
crazy & 1 \\
edgy & 1 \\
fun & 1 \\
healthy & 1 \\
nude & 1 \\
scary & 1 \\
shitty & 1 \\
\hline Total & 35 \\
\hline
\end{tabular}

According to Estonian orthography rules, if a stem of foreign origin is not entirely conventionalised and perceived as foreign, grammatical markers are separated by an apostrophe: cool'id kleidid 'cool dresses'. The stem would also be rendered in italics. However, this is not necessarily the case in blogs: as a rule, bloggers do not separate English stems from Estonian inflections. This may be not only a matter of convenience (takes less time) but also of perception (all items are written according to the same principles, no matter what their origin is). In the current article, the adjective is considered integrated into the matrix language when it agrees with the noun in number and case (in terminative, essive, abessive and comitative it agrees with the noun in number only). The use of an apostrophe is not taken into account, as it is a matter of orthography. 
In some cases, the spelling of the English adjective is adapted and it is spelled according to its pronunciation, for example instead of crazy the adjective is spelled kreisi. These words were also included in the analysis.

To analyse the adjectives, they were assorted into groups based on their sound structure. In my data, there were three types of adjectives that were integrated: 1) monosyllabic adjectives, 2) disyllabic adjectives ending with [i], and 3) disyllabic adjective in the nominative ending with $[\mathrm{k}]$.

\subsection{Monosyllabic adjectives}

In my data, often monosyllabic (hereafter, classification is based on the number of syllables in nominative) adjectives ending with a consonant are integrated into Estonian. The syllables are long and closed. Adjectives belonging to this group are cool (in 1 instance spelled khuul and in 1 instance kool), chill, deep (in both instances spelled diip), clean, crap (spelled kräp), fun and nude (see Table 4 for total number of occurrences).

The reason these adjectives are integrated into Estonian might be that they decline as the prototype word hell 'tender': there is only quantity alternation $(\mathrm{Q} 3$ in nominative, Q2 in genitive, Q3 in partitive, like hell : hella: hella) and integrating the adjective is not difficult. Consider example 3 where adjective cool is used. In my data, this adjective was always integrated.

(3) B9

Lindexi-s on cooli-d päikseka-d müügi-l.

Lindex-INE be.3sg cool-PL.NOM sun glass-PL.NOM sale-ADE

'They are selling cool sunglasses in Lindex'

Although in the current article the use of apostrophe is not analysed, example 4 is presented to show metalinguistic awareness (Verschik 2017: 20-21) of some bloggers: an apostrophe is used to mark the border of the loan adjective and the Estonian stem vowel that marks the genitive. So, the blogger has a good idea where the border between the stem and case markers lies and that the stem is not of Estonian origin. 
(4) B12

$\begin{array}{lllll}\text { ole-n } & \text { jaga-mata } & \text { jät-nud } & \text { ühe } & \text { eriti }\end{array}$

have-1SG share-SUP.ABE leave-PST.PTCP one.GEN very

fun'i ja ägeda pildistamise kraami

fun.GEN and awesome.Gen photoshoot.GEN stuff.GEN

'I have not shared one very fun and awesome photoshoot stuff'

Example 5 is a strong candidate for non-integration as it would fit in the category described in section 7.1. When used in any case other than the nominative or partitive, there would be a question about the plosive $p$, as it is subjected to quantity alternation, e.g. Estonian järsk 'steep', järsu in genitive and järsku in partitive. In oral use, English words are subjected to this type of alternation, but it is hard to predict whether this is applied in writing as well, because the body of data on English-Estonian bilingual internet communication is rather small and the examples of this kind are hard to find. Certain borrowings are conventionalised: they have been established as a normal word and all members use it (Backus 2012: 11). For example, meik 'make-up' (NOM meik: GEN meigi : PART meiki) is established in Estonian orthography and quantity alternation is reflected in the spelling as well. In this example 5, the phrase is in the partitive, so the quantity of the plosive remains the same as in the nominative and this is probably why the adjective is integrated.

(5) B10

oli-n juba oma pea-s järgmis-t

be:PST-1sG already own.GEN head-INE next-PART

diipi blogipostitus-t kirjuta-ma-s

deep.PART blogpost-PART write-SUP-INE

'I was already writing the next deep blogpost in my head'

Example 6 is from vlog${ }^{2}$. The example presents how the adjective nude is integrated. This is interesting, because in blogs this adjective was never integrated. The reason might be that in writing, the blogger had to consider if and how to add a stem vowel and the case marker, but in oral speech, the vlogger does not have to think about this. Thus, it is easier to integrate the adjective.

2 Hereafter, the examples from vlogs are based on my transcription. 
(6) V5

pani-n siukse nude'i huulepulga

put:PST-1SG such nude.GEN lipstick.GEN

'I used this nude lipstick'

\subsection{Disyllabic adjectives ending with [i]}

English adjectives ending with [i] (in orthography usually $y$ ) are good candidates for integration. As all Estonian words end with a vowel in the genitive and all other cases in the singular (bar partitive) are based on the genitive, English adjectives ending with $y$ that are pronounced in the second degree of quantity are attractive for integration as the syllabic structure is similar to Estonian. In my data, adjectives belonging to this group are fancy, crazy (spelled kreisi), edgy, healthy, scary and shitty (see Table 4 for total number of occurrences).

The prototype word here could be tubli 'diligent, appropriate', that is, disyllabic, first syllable is long and closed, the word ends with a vowel, it is in the second degree of quantity and there is no grade alternation (e.g. NOM tubli: GEN tubli: PART tubli). Consider example 7 where adjective edgy is used. It also illustrates how the phoneme $i$ (orthographic $y$ ) is reinterpreted as Estonian adjective stem vowel $i$ (similar to adjectives like nadi 'poor, bad', tubli 'diligent, appropriate', etc.).

(7) B2

puhas-t musta, valge-t, halli ja

pure-PART black.PART white-PART grey.PART and

edgy'-t minimalismi sealt ei leia

edgy-PART minimalism.PART there:ABL NEG find

'pure black, white, grey and edgy minimalism is not found there'

Example 8 illustrates the use of adjective crazy spelled according to Estonian orthography rules. As the adjective is conventionalised in Estonian and common in spoken language, it is not very surprising it is written according to Estonian orthography. The adjective is also used in comparative form, showing that the adjective is conventionalised and thus fully integrated into Estonian. In this example, the use of Estonian orthography might trigger the use of the Estonian grammatical markers. 
(8) B3

$\begin{array}{llllll}\text { Suve } & \text { üks } & \text { kreisi-ma-i-d } & \text { mälestusi } & \text { on } & 3 \\ \text { Summer.GEN } & \text { one } & \text { crazy-COMP-PL-PART } & \text { memory.PL.PART } & \text { be.3sG } & \text { three }\end{array}$

nädala-t hääletamis-t Euroopa-s oma kalli Kadri-ga!

week-PART hitchhike-PART Europe-INE own.GEN dear.geN Kadri-COM!

'One of the craziest memories is hiking for 3 weeks in Europe with my dear

Kadri!'

In example 9 the comparative form is used, and as the noun is in plural, the English adjective receives the Estonian plural marker, and an apostrophe is used to mark where the English adjective ends and where the Estonian grammatical markers begin. This might be a sign that the blogger is extremely aware of her multilingual language use.

(9) B7

Seal on natuke keerulise-ma-i-d ja

There:ADE be.3SG a bit complex-COMP-PL-PART and

fancy'-ma-i-d toite

fancy-COMP-PL-PART dish.PL.PART

'There are a bit more complex and fancy dishes'

\subsection{Disyllabic adjective in the nominative ending with [k]}

Disyllabic adjectives in the nominative ending with [k] (in orthography mostly $c$ ) are good candidates for integration as the prototype word would be lapik 'flat', the assumed stem vowel would be $u$. There is no grade alternation, so this kind of adjective is simple to integrate. Despite of this, adjective basic was integrated only in 3 examples out of 9, all 3 examples came from vloggers. Consider example 10.

(10) V2

siin on nagu need $\mathbf{3}$ basicu-t asja

here be.3sG like these 3 basic-PART thing.PART

'here are the 3 basic things'

This suggests that the question of integration here is not about phonotactics, but it is rather connected with the choice a blogger must make while writing: if and how to add a case marker as the writing ends 
with a $c$ (in Estonian it should be $k$ ) and what stem vowel would be appropriate.

\section{Estonian participles formed from English adjectives}

The language use in blogs and vlogs give the impression that bloggers and vloggers are skilful and flexible in the use of both languages. Their command of language is such that they are able to combine loan adjective and native participle markers and form Estonian past and present participles which accommodate Estonian (the matrix language). The present participle is declined like an adjective (marker $-v$ for active and -tav for passive); the past participle is indeclinable (marker -nud for active and -tud for passive). Table 5 presents the Estonian participles formed from English adjectives. Altogether, there were 6 participles. Present participles are analysed in section 6.1 and past participles in section 6.2.

Table 5. Estonian participles that were formed from English adjectives

\begin{tabular}{lc}
\hline English adjective & Number of tokens \\
\hline matchiv 'matching' & 3 \\
boostiv 'boosting' & 1 \\
forsitud 'forced' & 1 \\
upgradetud 'upgraded' & 1 \\
\hline Total & 6 \\
\hline
\end{tabular}

\subsection{Present participles}

The marker of the present participle is $-v$, which is added to the stem (e.g. sädele- $v$ 'sparkling' sparkle-PRS.PTCP) or to the marker of impersonal voice (e.g. värvi-ta-v 'colourable' colour-IMPS-PRS.PTCP). In English, a present participle is marked with -ing (e.g. sparkling). Although grammatically the present participle is a verb form, it is similar to an adjective and syntactically behaves as an adjective, i.e. both are used to modify a noun and can be predicative or adverbial. Similarly to an adjective, the present participle agrees with the noun it modifies in number and case, i.e. in Estonian, it agrees fully (e.g. 
sädele-va-te-s kleiti-de-s 'in sparkling dresses' sparkle-PRS.PTCP-PL-INE dress-PL-INE), whilst in English, there is no agreement (e.g. in sparkling dresses).

In my data, present participles matching and boosting occurred (see Table 5). In the examples presented below, the English verb stem and the Estonian present participle marker are combined, forming a participle that agrees with the Estonian noun in number and case. Consider example 11 where adjective matching is used to form a participle.

(11) B1

eriti jlus jää-b muidugi siis, kui leia-d

especially beautiful stay-3sG of course then if find-2sG

alla ka matchi-va huulepliiatsi

under also match-PRS.PTCP.GEN lip pencil.GEN

'it stays especially beautiful, if you find a matching lip pencil'

In example 12, the participle is integrated. This example is particularly interesting, as the adjective is a mixed copy (a compound word that is partially Estonian and partially English). The words preceding and following the English part are foreign words, so this adjective would be attractive for non-integration. In other blog posts, the blogger has shown frequent use of English idioms and expressions, so this type of integration might not be difficult for her.

(12) B6

Tõenäosuse suurendamise-ks, võta

Probability.GEN increase-TRL take.IMP.2SG

hormoone-boosti-va-i-d

preparaate

hormone boost-PRS.PTCP-PL-PART preparation.PL.PART

'To increase the probability, take hormone boosting preparations'

\subsection{Past participle}

In 2 instances, English adjectives were found combined with the Estonian past participle marker (forsitud and upgradetud, see Table 5). The past participle refers to an attribute or state that arose in the past. In Estonian, this participle is marked with -nud (personal voice) or -tud (impersonal voice), e.g. värvi-tud juukse-d 'coloured hair' (colour-PST.PTCP 
hair-PL.NOM). Similarly, to the adjective, the past participle can be used as an attribute, predicative or an adverbial. Both in English and in Estonian, the past participle does not agree with the noun it modifies. Consider past participle forsitud 'forced' in example 13.

(13) B4

Jälle see forsi-tud naeratus

Again that force-PST.PTCP smile

'Again that forced smile'

In example 14, the orthography of the participle contains a vowel $e$ which is not pronounced. The rules of Estonian orthography would expect the form upgrade'itud, where the apostrophe shows that the final vowel $e$ is not pronounced. So, the stem vowel $i$ would be expected here as it is usual for lexical borrowings.

(14) B5

täiskasvanu-i-d lõbusta-b see sama upgrade-tud jõuluvana adult-PL-PART amuse-3SG that same upgrade-PST.PTCP Santa Claus 'adults are amused by that same upgraded Santa Claus'

\section{Non-integration of English adjective where the syntactic position requires it}

Although "[a]djectives tend to be integrated syntactically into the position of the attribute in the recipient language" (Matras 2009: 188), in 46 instances out of 84 ( 37 instances in blogs and 9 instances in vlogs) the English adjective was not integrated into Estonian, even though the syntactic position required it. English adjectives that did not agree with the Estonian noun are listed in Table 6.

Often adjectives are not integrated when their form in the embedded language does not fit into the matrix language inflectional classes (e.g. sound structure), and due to this the loan adjective must undergo derivational modifications to fit into the specific inflectional class. Matras also provides an example from Urdu, where otherwise inflectional agreement of adjectives is not used in case of English-derived adjectives (Matras 2009: 188-189). 
Table 6. Adjectives that were not morphosyntactically integrated

\begin{tabular}{|c|c|}
\hline English adjective & Number of tokens \\
\hline basic & 9 \\
\hline awesome & 6 \\
\hline random & 5 \\
\hline nude & 4 \\
\hline casual & 3 \\
\hline classic & 3 \\
\hline tribal & 3 \\
\hline appreciative & 1 \\
\hline badass & 1 \\
\hline beige & 1 \\
\hline conscious & 1 \\
\hline fake & 1 \\
\hline favourite & 1 \\
\hline flat & 1 \\
\hline high-end & 1 \\
\hline hot & 1 \\
\hline magical & 1 \\
\hline safe & 1 \\
\hline satin & 1 \\
\hline smart & 1 \\
\hline Total & 47 \\
\hline
\end{tabular}

Based on their sound structure, adjectives that were not integrated were divided into three groups: 1) monosyllabic adjectives ending with a plosive, 2) disyllabic adjectives ending with a consonant both in writing and pronunciation, 3) adjectives ending with a vowel in spelling, but with a consonant in pronunciation.

\subsection{Monosyllabic adjectives ending with a plosive}

The current section discusses English adjectives that do not agree with the Estonian noun in number or case, despite being phonotactically similar to the adjectives presented in section 5.1. The adjectives 
discussed in section 5.1 are monosyllabic in the nominative and the syllable is closed and long. Adjectives discussed here end with a plosive and there is quantity alternation.

The reason for non-agreement might be quantity alternation: in written text the blogger needs to decide on the spelling, i.e. whether there is a single or double $k, p, t$, corresponding to different quantities (e.g. in the nominative, the double character $k$ in pikk 'long, tall' corresponds to Q3, and in the genitive, it is written with a single $k$, as in pika, which corresponds to Q2). In some cases, there would be the need to decide how to mark weakening grade alternation. Based on prototype word virk 'hard-working' (NOM virk: GEN virga : PART virka) the adapted version of the adjective fake could be declined feik (strong grade, Q3) : feigi (weak grade, Q2) : feiki (strong grade, Q3). So, it might be easier to not integrate this kind of adjectives. This section comprises of adjectives fake (spelled feik), flat, hot, nude, smart.

In examples $15 \mathrm{a}-17 \mathrm{a}$, the adjective does not agree with the noun, probably due to the plosive and quantity alternation. In examples $15 \mathrm{a}$ and 16a, the potentially-possible agreeing form partitive would require the gemination of the plosive. This raises the question of whether there is a quantity alternation in the pronunciation, and moreover in the spelling, and if so, how to mark it. Although there are words in Estonian that are written with one plosive, but pronounced in the third degree of quantity, this matter is easier to avoid and decide not to integrate the adjective. See example $15 \mathrm{a}$ and hypothetically possible agreement in $15 \mathrm{~b}$.

(15a) B22

Ja ükspäev vaata-si-n Asose-st (kogemata)

And one day look-PST-1sG Asos-elA (accidentally)

minge- $\mathrm{i}-\mathrm{d}$ superhot kontsakingi

some-PL-PART superhot.NOM shoe.PL.PART

'And one day I was (accidentally) looking at some superhot shoes from Asos'

superhotte kontsakingi

superhot.PL.PART heel.PL.PART

'superhot heels' 
In example 16a, the English adjective is adapted. One would presume that this would favour its integration, but this is not the case here. Due to the plosive at the end of the word, integration would mean that the blogger would need to decide whether quantity alternation should be used as in hypothetical example 16b. Also, the blogger might use the Estonian compound noun vôltssall ('fake scarf', fake.NOM + scarf) as an example where the Estonian equivalent võlts 'fake' stays in the nominative.

(16a) B21

Ehk nüüd sa-i minu-st ka üks nende-st

So now become-PST.3sg me-ELA too one these-ELA

tüdruku-te-st, kes oma-b feik Burberry salli

girl-PL-ELA who own-3SG fake.NOM Burberry:GEN scarf.PART

'So now I became one of those girls who own a fake Burberry scarf, too'

feiki Burberry salli

fake.PART Burberry:GEN scarf.PART

'a fake Burberry scarf'

In example $17 \mathrm{a}$, the adjective should be in the genitive, so for it to have been integrated, only the addition of a stem vowel would have been needed. As the word ends with a plosive, the blogger needed to decide whether to imply quantity alternation as shown in the hypothetical example 17b. Also, here the Estonian equivalent täistald 'wedge-shaped sole' (literally 'full sole', full.NOM + sole) might affect agreement as it is a compound noun where the first word stays in the nominative.

(17a) B5

$\begin{array}{lllllll}\text { Vali-si-n } & \text { välja } & \text { flat } & \text { talla-ga } & \text { ja } & \text { samas } & \text { ka } \\ \text { choose-PST-1sG } & \text { out } & \text { flat.NOM } & \text { sole-COM } & \text { and } & \text { also } & \text { too } \\ \text { kerge } & \text { kontsa-ga } & \text { saapa-d } & & & & \\ \text { light.GEN heel-COM } & \text { boot-PL.NOM } & & & \\ \text { 'I chose boots with flat sole and with a light heel' } & \end{array}$

flati talla-ga

flat.GEN sole-com

'with a flat sole' 


\subsection{Disyllabic adjectives ending with a consonant both in writing and pronunciation}

Adjectives badass, basic, casual, classic, conscious, high-end, magical, random, satin and tribal belong to this group (see Table 6 for number of occurrences). These adjectives ending with a consonant both in writing and pronunciation, they are good candidates for integration as there are several Estonian adjectives to use as a prototype word, for example ilus 'beautiful', pahur 'grumpy', lapik 'flat'. There is no stem alternation, only the stem vowel needs to be added, so it would be simple to integrate these adjectives. Hence, the reason for non-integration is not because of phonotactics.

As stated in section 5.3, adjectives ending with [k] (in orthography mostly $c$ ) are good candidates for integration as the prototype word would be lapik 'flat', the assumed stem vowel would be $u$. However, usually the adjectives basic and classic remained uninflected. Most likely this is due to uncertainty what stem vowel to use and whether to use $c$ or $k$ in writing. Consider example 18 .

(18a) V4

mina looda-n, et te jätka-te oma I hope-1sg that you continue-2PL own.geN

basic eluviisi-ga ka peale se-da video-t basic lifestyle-COM also after this-PART video-PART 'I hope you continue with your basic lifestyle after this video'

basicu eluviisi-ga

basic.GeN eluviis-COM

'with basic lifestyle'

In example 19a, the adjective satin is used when describing a nail polish. It is not integrated, although there is a noun satiin 'satin', that could be used as a prototype word. Based on it, only the stem vowel $i$ needs to be added for integration. However, here the adjective has a figurative and metaphorical meaning (smooth and silky) that might not be associated with the fabric satin. 
(19a) B16

Satin viimistluse-ga (toon 35) ei osta-ks

Satin finishing-COM (shade 35) NEG buy-COND

'I would not buy [a nail polish] with satin finish (shade 35).'

satini viimistlusega

satin.GEN finishing-COM

'with satin finish'

In many cases, adjectives with a foreign syllabic structure were not integrated. In examples 20a and $21 \mathrm{a}$, adjectives casual and magical are used. As they have three syllables and the last syllable begins with a vowel, they would fit in the declensional class seminar 'seminar', but there are no adjectives in that class. The adjective casual could be hypothetically used to form a respective Estonian adjective kasuaalne, but that would be in an upper register or ironical. Thus, here the reason for non-integration might be that the phonetic structure is foreign and does not fit with the Estonian declensional classes.

(20a) B3

Eile leid-si-n Only poe-st casual jope

Yesterday find-PST-1SG Only.GeN store-ELA casual.NOM jacket.GEN

'Yesterday I found a casual jacket at the Only store'

casual'i jope

casual.gEN jacket.GEN

'a casual jacket'

Although magical in example 21a is a good candidate for integration (no stem alternation), it does not receive any marking. As explained above, the absence of an appropriate prototype word and the length of this adjective (usually longer adjectives are derivatives, for example, rohekas 'greenish' and paratamatu 'unavoidable', but these have different sounds) is most likely why this adjective does not agree with the noun. 


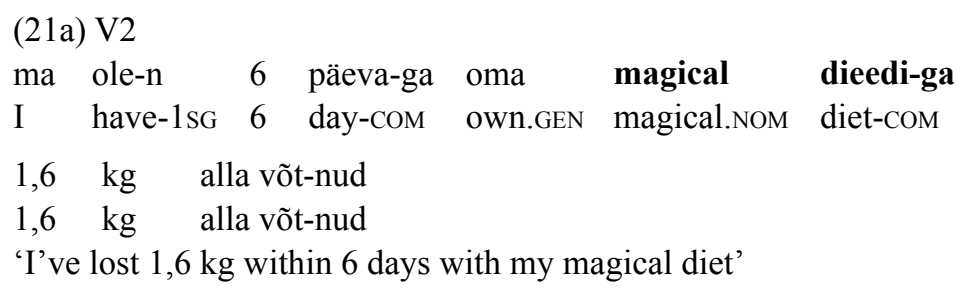

(21b)

magicali dieedi-ga

magical.GEN diet-COM

'magical diet'

In example 22, it could be presumed that the adjective conscious would be integrated using an Estonian stem vowel $i$, which is usually added to loan words, though there is a lack of examples for how this adjective would be integrated. According to Google search, there is one instance where this adjective is integrated: Kellele H\&Mi Consciousi kollektsiooni-d ehk võorad on .. 'To those who are not familiar with the H\&M Conscious.GEN collection-PL.NOM ...'. Here, the adjective is part of the name of the collection and the author is not consistent as regards integrating it, so this situation is rather exceptional, but it shows that hypothetically this form is possible.

(22a) B20

see on $=$ gi conscious kollektsiooni-de-le omane

this be. $3 \mathrm{SG}=$ too conscious.NOM collection-PL-ALL inherent

'This is inherent to conscious collections'

consiousi-de/te-le kollektsiooni-de-le

conscious-PL-ALL collection-PL-ALL

'conscious collections'

In example 23a, the English adjective random is used. Here the reason for non-integration might be that there is a lack of a suitable prototype word. In Estonian adjectives that are disyllabic in the nominative ending with $m$ are mostly in comparative degree (e.g. positive suur 'big': comparative suure- $m$ 'bigger': genitive comparative suure-ma 'of a/the bigger': partitive comparative suure-ma-t). If the 
syntactic position requires, it agrees with the noun in number and case, see examples 8 and 9. Moreover, there are nouns ending with $m$ (e.g. valem 'formula', kogum 'conglomeration') with the genitive stem ending with $i$ (genitive valemi) which could be used as a pattern because nouns and adjectives belonging to the same declensional class are declined the same way. This also holds true for the adjective awesome in example 25 as its pronunciation also ends with $m$.

(23a) B8

$\begin{array}{lllll}\text { Nimeta } & \mathbf{5} & \text { random } & \text { fakti } & \text { enda-st } \\ \text { Name.IMP.2SG } & 5 & \text { random.NOM } & \text { fact.PART } & \text { yourself-ELA } \\ \text { 'name } 5 \text { random facts about yourself' } & \end{array}$

5 randomi-t fakti

5 random-PART fact.PART

'5 random facts'

Compound adjectives badass and high-end would be easy to integrate as there is no quality alternation and only the stem vowel should be added. Here, the stem vowel $i$ would be expected as it is normal for lexical borrowings. Consider badass in example 24a and $24 \mathrm{~b}$.

(24a) B15

Nii mõnus outfit ja nii chilli-d badass pildi-d

So comfy outfit and so chill-NOM.PL badass picture-NOM.PL

'So comfy outfit and so chill badass pictures'

badassi-d pildi-d

badass-PL.NOM picture-PL.NOM

'badass pictures'

\subsection{Adjectives ending with a vowel in spelling, but with a consonant in pronunciation}

One of the rules of Estonian spelling is that is based on phonetic principles, while this is not the case in English, where spelling and pronunciation may sometimes substantially diverge. According to Estonian orthography, when the word is pronounced differently from its spelling, 
the case marker is added with an apostrophe. Adding it takes more time and effort, so for the sake of simplicity the adjective is morphosyntactically not integrated. Due to this reason, adjectives appreciative, awesome (in 3 instances spelled oosõm), beige, favourite and safe were not integrated (see Table 6).

In examples 25a and 26a, adjectives end with a vowel that is not pronounced and integrating them would not be a straightforward matter. That said, the adjective awesome is sometimes adapted based on its pronunciation: oosõm auto 'awesome car'. Such spelling should predispose integration, as it would require only adding a stem vowel and case marking. This shows there are other characteristics that effect integration; see hypothetical examples $25 \mathrm{~b}$ and $26 \mathrm{~b}$.

(25a) B19

Awesome pildi-d, awesome teksa-d!

Awesome.NOM picture-PL.NOM awesome.NOM jeans-PL.NOM

'Awesome pictures, awesome jeans!'

awesome'i-d pildi-d awesome'i-d teksa-d

awesome-PL.NOM picture-PL.NOM awesome-PL.NOM jean-PL.NOM

'Awesome pictures, awesome jeans!'

In example 26a adjectives beige and nude are used. It is interesting that the blogger added the Estonian word for beige in brackets, which could be a hint for integrating the adjectives. The other aspect is that in this example the comitative is used and in the comitative agreement is partial, i.e. the adjective is used in the genitive. In Estonian, in the genitive case a stem vowel is always added, so the morphological structure of these adjectives could be construed as the genitive form (this is shown in the hypothetical example 26b).

(26a) B20

Jah, mu-lle see nii meeldi-b ja eriti kombineeritult

Yes me-ALL it so like-3sg and especially combine.ADV

koos nude/ beige (beez) värvi-ga

with nude.NOM beige.NOM (beige) color-COM

'Yes, I like it, especially combined with nude/beige (beez) colour' 
(26b)

nude'i beige'i värvi-ga

nude.GEN beige.GEN colour-COM

'with nude beige colour'

The same occurs in example 27a. This example is particularly interesting, because when pronounced, the last syllable of the adjective is similar to the marking of the Estonian present participle, which always agrees with the noun in number and case (see section 6.1), e.g. impressi-va-d artikli-d (impressive-PRS.PTCP-PL.NOM article-PL.NOM) 'impressive articles' (heard by the author in oral communication). The reason why the adjective appreciative is not integrated into Estonian might be the length of the adjective: in section 5 it was stated that usually mono- and disyllabic adjectives agree with the noun they modify.

(27a) B5

$\begin{array}{llllll}\text { Siinkohal } & \text { taha-ks } & \text { teh-a } & \text { sellise } & \text { appreciative } & \text { momendi, } \\ \text { Here } & \text { want-COND } & \text { do-INF } & \text { this.GEN } & \text { appreciative.NOM } & \text { moment.GEN }\end{array}$

et see 1,5 aasta-t oli üks laheda-ma-i-d mu

that this 1,5 year-PART be:PST.3SG one cool-COMP-PL-PART my elus.

life-INE

'Here I would like to have an appreciative moment and say that this 1.5 years was one of the coolest in my life.'

sellise appreciati-va momendi

this.GEN appreciate-PRS.PTCP.GEN moment.GEN

'this appreciative moment'

In example 28a, the lack of an appropriate prototype word might also affect integrating it. The adjective ends with an [f] in pronunciation, but there are no adjectives in Estonian ending with this consonant, although there is a noun seif 'bank vault' that is pronounced similarly (NOM seif: GEN seifi: PART seifi). Still, as the writing of the adjective safe ends with a vowel it might be confusing to add another vowel. 
(28a) V2

lähe-n iga-ks juhu-ks safe valiku peale

go-1SG every-TR case-TR safe.NOM choice.GEN on

'I'll use a safe choice'

safe'i valiku

safe.GEN choice.GEN

'safe choice'

In example 29a, the gemination of the plosive might also play a role. This raises the question of whether there is a quantity alternation in the pronunciation.

(29a) V4

okei, need on mu favourite vansi-d

okay, these be.3sG me.GEN favourite.NOM vans-PL.NOM

'Okay, these are my favourite Vans'

favourite'i-d vansi-d

favourite-PL.NOM vans-PL.NOM

'favourite vans'

\section{Complicated to determine}

In 3 cases, due to the syntactic position it is impossible to determine whether the adjective is integrated, these adjectives are comfy, fancy and fluffy. This is due to the final [i], that can be interpreted as the stem vowel that appears in the genitive.

The prototype word would be tubli 'diligent' (NOM tubli: GEN tubli : PART tublit) as in section 5.2. Based on similar adjectives fancy, crazy, edgy etc. that were integrated (see section 5.2), it might be assumed that comfy, fancy and fluffy are in genitive. Consider fluffy in example 30. 
(30) B20

$\begin{array}{llllll}\text { Selle } & \text { roosa } & \text { fluffy } & \text { jaki } & \text { soeta-si-n } & \text { eelmise-1 } \\ \text { This.GEN } & \text { pink.GEN } & \text { fluffy.GEN? } & \begin{array}{l}\text { jacket.GEN } \\ \text { buy-PST-1SG }\end{array} & \text { last-ADE } \\ \text { aasta-1 } & \text { Zara-st } & & \\ \text { year-ADE } & \text { Zara-ELA } & & \\ \text { 'I got this pink fluffy jacket last year from Zara' }\end{array}$

\section{Discussion}

According to the MLF model, the matrix language provides the morphosyntactic frame for a sentence (Myers-Scotton 1997), so the premise of this article was that in English-Estonian language contact situations English adjectives receive Estonian case and number assignment. However, my data and analysis showed that this is far more complex.

The analysis showed that the morphological compatibility of English adjectives with the Estonian declension system favours integrating certain adjectives. English adjectives which are morphologically similar to those of Estonian often agree with the Estonian noun if intuitively a suitable Estonian inflectional pattern is found. Generally in these cases, only a stem vowel and the Estonian case marker need to be added for agreement. For example, adjectives like cool and chill are similar to the Estonian adjective hell 'tender' and they were integrated. Furthermore, English words that are monosyllabic and end with a consonant both in spelling and pronunciation are good candidates to conventionalize in Estonian, there are several examples of English nouns that have been easily adapted, e.g. mopp ('mop', NOM mopp : GEN mopi : PART moppi), räpp ('rap' NOM räpp : GEN räpi: PART räppi).

Also, all adjectives ending with [i] ( $y$ in spelling) always agreed with the noun, moreover, in several cases they were used in a comparative form (see adjectives crazy and fancy in examples 8 and 9). This shows that if a loan adjective has a sound structure similar to an Estonian adjective it is not perceived as a foreign element and will most likely receive case and number marking.

At the same time, adjectives with a sound structure different from that of Estonian adjectives were not integrated. For example, adjectives casual and magical have three syllables and in casual the last syllable begins with a vowel, this is perceived as foreign because it is common 
to loan words. Due to this it might be difficult to choose a suitable model word to use as an example for adding the stem vowel and case marker.

Another factor that causes non-agreement is the divergency of the spelling and pronunciation. For example, adjectives awesome and safe were probably not integrated due to this. In my data, there was only 1 instance where an adjective pronounced differently from its spelling was integrated: adjective nude in a vlog post. Although, here the medium might play a role as in vlogs and in oral speech it is easier to integrate an adjective because the vlogger does not have to consider spelling. In cases where spelling and pronunciation differ, adding a case marker in writing is not a straightforward matter, it takes more time and effort and it is easier to keep the adjective uninflected.

In my data, there are examples when structural criteria are met, yet some adjectives do not agree with the nouns. Consider monosyllabic adjectives ending with a plosive, like flat and hot, that despite fitting into declensional class exemplified with pikk 'tall, long' did not take on inflections. Factors that play a role here are quantity alternation (e.g. it is difficult to decide how the changes in the quantity of the plosive should be marked in writing) and spelling (if the spelling and pronunciation differ, it might be quite confusing to add the markers).

In some cases, English adjectives may be uninflected due to their close association with compound words. Consider adjectives fake, favourite and flat in examples 16a, 29a and 17a. In similar expressions the Estonian equivalents of these adjectives would be in the nominative and as the first part of a compound noun: võltssall 'fake scarf' (fake.NOM + scarf), lemmiktossud 'favourite sneakers' (favourite.NOM + sneakers) and täistald (literally: 'full sole', full.NOM + sole). Thus, the pattern of compound nouns may be applied here.

However, structural factors do not explain everything. As mentioned in section 3, Zabrodskaja (2009: 368) found that integration depends on structural factors only to a certain extent: the noun fitting into any of the Russian noun declension classes was less important. She proposed that factors that rather play a role are individual preferences, types of discourse, oral or written modality etc.

In addition, the choice of medium might also have an effect. In oral speech some of the factors mentioned above do not pose problems, for example, how to write the plosive when the adjective is pronounced in 
the second quantity degree. In case of the differences in spelling and pronunciation, in oral speech it is easier to avoid the uncertainty around using the apostrophe and adding an appropriate stem vowel. Consider adjectives basic and nude that did not agree with the noun in blogs (writing) but agreed in vlogs (oral speech). For example, when integrating the adjective basic, the blogger has to consider what stem vowel to use and whether to use $c$ or $k$ in writing. However, this does not pose a problem in oral speech. Although, there were too few examples to draw any final conclusions, I believe the choice of medium is one aspect that plays a role in agreement. This idea is also supported by the fact that in my data, all 5 vloggers sometimes or always integrated the adjective (among bloggers 14 out of 21 sometimes or always integrated the adjective and 7 bloggers never used agreement).

Lastly, as mentioned in section 3, a bilingual does not need the same kind of mechanisms of integration as a monolingual does as they have greater knowledge and resources to use (Cook 2016). It has been noted that bilinguals do not need to apply full morphosyntactic integration for understanding (Leisiö 2001, Zabrodskaja and Verschik 2014).

\section{Conclusions}

This article investigates the agreement of English adjectives used with Estonian nouns in Estonian blogs and vlogs. Although the literature suggests that in language contact situations loan adjectives are integrated, this is not always the case in my data. The main question was what are the factors that favour integrating loan adjectives from English into Estonian. For that, 84 examples from 29 informants were analysed. The adjective agreed with the Estonian noun in case and number in 35 instances ( 25 instances from blogs and 10 instances from vlogs), in 46 instances the adjective remained uninflected (respectively 37 and 9 instances), in 3 instances it was complicated to determine agreement due to the syntactic position.

The factors that play a role are individual preferences and choice of medium (oral speech or written text). 3 out of 5 vloggers always integrated the adjective, the other 2 vloggers sometimes integrated the adjective and sometimes did not. Among bloggers 7 bloggers out of 21 always integrated the adjective, 7 bloggers never integrated and 
7 bloggers used both ways. This shows that in oral speech integrating the adjective is easier. Structural factors are also important: if intuitively a suitable Estonian inflectional pattern is found the loan adjective often agrees with the Estonian noun, however, this is not always decisive.

To answer the question, to agree or not to agree, the answer is: it depends. Although in my data, adjectives were integrated in 35 instances and were not integrated in 46 instances out of 84, the analysis supports the idea, that if English adjectives fit into the Estonian inflectional system and there is no need to consider spelling (in oral speech), the adjective is integrated. This is also illustrated by the fact that 19 informants out of 26 sometimes or always integrated the adjective. Albeit, there are several factors that may affect non-agreement, like quantity alternation, spelling, personal preference. It seems that the agreement of a loan adjective is potentially redundant and unstable and depends on several factors mentioned above.

As the analysis is based on a small corpus, it is difficult to draw definite conclusions. Therefore, at the present stage only tendencies can be noted. For further conclusions, more oral data should be collected to compare written texts and oral speech. Also, a perception test would help to understand the agreement system concerning loan adjectives. It might be that these adjectives are handled as islands of embedded language that do not allow inflection.

\title{
Acknowledgment
}

The research leading to these results was supported by Professor Anna Verschik, who gave me access to her corpus of Estonian blogs.

\author{
Addresses \\ Helin Kask \\ Tallinn University \\ Narva mnt 25 \\ 10120 Tallinn \\ Estonia \\ E-mail: helin.kask@tlu.ee
}




\section{Abbreviations}

AdjP - adjective phrase, ABL - ablative, ADE - adessive, ALL - allative, COM - comitative, COMP - comparative, COND - conditional, ELA - elative, GEN - genitive, IMP - imperative, IMPS - impersonal, INE - inessive, INF - infinitive, ILL - illative, MLF - matrix language frame model, $\mathrm{N}$ - noun, NEG - negative, NOM - nominative, NP - noun phrase, PL - plural, PRS - present, PART - partitive, PST - past, PTCP - participle, SG - singular, SUP - supine, TR - translative

\section{References}

Alumäe, Tanel, Ottokar Tilk, and Asadullah (2019) "Advanced rich transcription system for Estonian speech". In Kadri Muischnek and Kaili Müürisep, eds. Human language technologies - the Baltic perspective: proceedings of the eighth international conference Baltic HLT 2018, 1-8. (Frontiers in Artificial Intelligence and Applications, 307.) Amsterdam, Berlin, and Washington, DC: IOS Press.

Aran, Oya, Joan-Isaac Biel and Daniel Gatica-Perez (2014) "Broadcasting oneself: visual discovery of vlogging styles". IEEE Transactions on Multimedia 16, 1, 201215. https://doi.org/10.1109/TMM.2013.2284893

Backus, Ad (2001) "The role of semantic specificity in insertional codeswitching: evidence from Dutch-Turkish". In Rodolfo Jacobson, ed. Codeswitching Worldwide II, vol. 2, 125-154. Berlin: Mouton de Gruyter.

Backus, Ad (2012) "A usage-based approach to borrowability". Tilburg Papers in Culture Studies. Paper 27. Available online at $<$ https://www.tilburguniversity.edu/ research/institutes-and-research-groups/babylon/tpcs $>$. Accessed on 04.12.2019.

Backus, Ad (2015) "A usage-based approach to codeswitching: the need for reconciling structure and function”. In Gerald Stell and Kofi Yakpo, eds. Code-switching between structural and sociolinguistic perspectives. Vol. 43, 19-37. Berlin: Mouton de Gruyter.

Backus, Ad and Anna Verschik (2012) "Copyability of (bound) morphology". In Lars Johanson and Martine Robbeets, eds. Copies versus cognates in bound morphology, 1-32. Boston, Leiden: Brill. https://doi.org/10.1163/9789004230477_007

Blommaert, Jan and Ad Backus (2011) Repertoires revisited: 'knowing language' in superdiversity. (Working Papers in Urban Language and Literacies, 67.) London King's College.

Cenoz, Jasone (2013) "Defining multilingualism". Annual Review of Applied Linguistics 33, 3-18. https://doi.org/10.1017/S026719051300007X

Cook, Vivian (2016) "Premises of multi-competence". In Vivian Cook and Li Wei, eds. The Cambridge handbook of linguistic multi-competence, 1-25. Cambridge: Cambridge University Press. 
Crystal, David (2007) Language and the Internet. Cambridge, New York: Cambridge University Press.

Ehala, Martin (2014) "Sustainability of the Estonian language". In Raivo Vetik, ed. Estonian Human Development Report 2014/2015, 191-198. Tallinn: SA Eesti Koostöökoda.

Erelt, Mati, ed. (2007) Estonian language. Tallinn: Teaduste Akadeemia Kirjastus.

Erelt, Mati (2008) "Veel kord vaegomadussõnadest". Keel ja Kirjandus 6, 442-449.

Fiedler, Sabine (2017) "Phraseological borrowing from English into German: cultural and pragmatic implications". Journal of Pragmatics 113, 89-102.

https://doi.org/10.1016/j.pragma.2017.03.002

Halmari, Helena (1997) Government and codeswitching: explaining American Finnish. (Studies in Bilingualism, 12.) Amsterdam and Philadelphia: John Benjamins.

Igav, Reet (2013) Inglise-eesti koodikopeerimine Facebooki vestlustes. MA Thesis. Institute of Estonian Language and Culture, Tallinn University.

Johanson, Lars (2002) Structural factors in Turkic language contacts. Richmond: Curzon.

Kask, Helin (2016) "English-Estonian code-copying in Estonian blogs". In Anna Verschik, ed. Philologia Estonica. Vol. 1, 80-101. Tallinn: Tallinn University Press. https://doi.org/10.22601/PET.2016.01.06

Kruusvall, Jüri (2015) “Keelteoskus ja keelte praktiline kasutamine”. In Kristina Kallas, Raivo Vetik, Jüri Kruusvall, Ellu Saar, Jelena Helemäe, Laura Kirss, Cenely Leppik, Külliki Seppel, Kats Kivistik, and Pille Ubakivi-Hadachi, eds. Eesti ühiskonna lõimumismonitooring 2015, 72-87. Tartu: Haridus- ja Teadusministeerium.

Kulper, Kerti (2015) "Eesti keskmine blogija: 29-aastane naine, kes kirjutab toidust, moest ja ilust". Postimees 13.04.2015 Available online at $<$ https://sobranna.postimees.ee/3152991/eesti-keskmine-blogija-29-aastane-naine-kes-kirjutab-toidustmoest-ja-ilust $>$. Accessed on 04.12.2019.

Leemets, Tiina (2002) "Mullivann, peenema nimega jaccusi”. Oma Keel 1, 41-46.

Leemets, Tiina (2003) "Inglise laenud sajandivahetuse eesti keeles". Keel ja Kirjandus $8,571-584$.

Leisiö, Larisa (2001) "Integration and gender assignment in Finland Russian". SKY Journal of Linguistics 14, 87-119.

Matras, Yaron (2009) Language contact. Cambridge and New York: Cambridge University Press.

Matras, Yaron (2012a) "An activity-oriented approach to contact-induced language change". In Claudine Chamoreau and Isabelle Léglise, eds. Dynamics of contactinduced language change, 17-52. Berlin: Mouton de Gruyter.

Matras, Yaron (2012b) "Contact, convergence, and typology". In Raymond Hickey, ed. The handbook of language contact, 66-85. Chichester: Wiley-Blackwell.

MeeMa (2014) "Keeleoskus ja võõrkeelte kasutamine Eestis eestlaste ja mitte-eestlaste seas". Mina. Maailm. Meedia. A Sociological Study in The University of Tartu. Tartu: Saar Poll.

Metslang, Helle (1994) “Kielet ja kontrastit”. Virittäjä 98, 2, 203-226. 
Myers-Scotton, Carol (1997) Duelling languages: grammatical structure in codeswitching. Oxford: Clarendon Press.

ÕS $2018=$ Eesti õigekeelsussõnaraamat ÕS 2018. Toim. Maire Raadik. Koost. Tiiu Erelt, Tiina Leemets, Sirje Mäearu, Maire Raadik. Tallinn: Eesti Keele Sihtasutus.

Peebo, Jaak (1997) Eesti keele muutkonnad. Tartu: Tartu Ülikooli Kirjastus.

Peterson, Elizabeth (2017) "The nativization of pragmatic borrowings in remote language contact situations”. Journal of Pragmatics 113, 116-126.

https://doi.org/10.1016/j.pragma.2017.02.012

Peterson, Elizabeth and Johanna Vaattovaara (2014) "Kiitos and pliis: The relationship of native and borrowed politeness markers in Finnish". Journal of Politeness Research 10, 2, 247-269. https://doi.org/10.1515/pr-2014-0011

Ratt, Silja (2017) Inglise-eesti koodikopeerimine Maria Rannavälja vlogides. BA Thesis. School of Humanities, Tallinn University.

Roosileht, Helin (2013) Inglise-eesti koodikopeerimine blogides. MA Thesis. Institute of Estonian Language and Culture, Tallinn University.

Stolz, Thomas (2015) “Adjective-noun agreement in language contact: loss, realignment and innovation". In Francesco Gardani, Peter Arkadiev, and Nino Amiridze, eds. Borrowed morphology, 269-301. Berlin, Boston, and Munich: De Gruyter Mouton.

Sutrop, Urmas (1997) “Entspricht Estnisch dem agglutinierenden Sprachtypus?” In Mati Erelt, ed. Estonian Typological Studies II, 199-219. Tartu: Tartu University Press.

Tammemägi, Anni and Martin Ehala (2012) "Koolinoorte keelehoiakud 2011. aastal". Keel ja Kirjandus 4, 241-260.

Teijeiro-Mosquera, Lucía, Joan-Isaac Biel, José Luis Alba-Castro, and Daniel GaticaPerez (2015) "What your face vlogs about: expressions of emotion and big-five traits impressions in YouTube". IEEE Transactions on Affective Computing 6, 2, 193-205. https://doi.org/10.1109/TAFFC.2014.2370044

Thurlow, Crispin, Laura Lengel, and Alice Tomic (2004) Computer mediated communication. London: Sage.

Tsitsipis, Lukas D (1998) A linguistic anthropology of praxis and language shift: Arvanitika (Albanian) and Greek in contact. Oxford: Clarendon Press.

Vaba, Marja (2010) Inglise-eesti koodikopeerimisest Tallinna Skype'i kontori kahe vestlusgrupi näitel. MA Thesis. Institute of Estonian Language and Culture, Tallinn University.

Verschik, Anna (2016) "Mixed copying in blogs: evidence from Estonian-Russian language contacts". Journal of Language Contact 9, 186-209.

https://doi.org/10.1163/19552629-00901008

Verschik, Anna (2017) "Metalinguistic comments and multilingual awareness: Estonian-Russian language contacts in blogs". Applied Linguistics Review 10, 3, 1-27. https://doi.org/10.1515/applirev-2017-0049

Verschik, Anna (2019) "English-Estonian code-copying in blogs: combining a contact linguistic and cognitive approach". In Eline Zenner, Ad Backus, and Winter-Froemel, eds. Cognitive contact linguistics: placing usage, meaning and mind at the core of contact-induced variation and change, 51-80. (Cognitive Linguistics Research, 62.) Berlin: Mouton De Gruyter. https://doi.org/10.1515/9783110619430-003 
Verschik, Anna and Helin Kask (2019) "Estonian-English code alternation in fashion blogs: structure, norms and meaning". In Sanita Lazdina and Heiko F. Marten, eds. Multilingualism in the Baltic states, 307-335. (Societal Discources, Language Policies and Contact Phenomena.) Palgrave Macmillan UK. https://doi.org/10.1057/978-1-137-56914-1_10

Viitso, Tiit-Rein (2007) “Nn vaegomadussõna ja selle taust”. Keel ja Kirjandus 11, $878-887$.

Voolaid, Helena (2017) Inglise-eesti koodikopeerimine raadiojaama Sky plus hommikuprogrammis. BA Thesis. School of Humanities, Tallinn University.

Zabrodskaja, Anastassia (2009). "Evaluating the Matrix Language Frame model on the basis of a Russian-Estonian codeswitching corpus". International Journal of Bilingualism 13, 3, 357-377. https://doi.org/10.1177/1367006908346629

Zabrodskaja, Anastassia and Anna Verschik (2014) "Morphology of Estonian items at the interface of Russian-Estonian language contact data". Sociolinguistic Studies 8, 3, 449-474. https://doi.org/10.1558/sols.v8i3.25505

Zenner, Eline, Ad Backus, and Esme Winter-Froemel (2019) "Introduction: placing usage, meaning and mind at the core of contact-induced variation and change". In Eline Zenner, Ad Backus, and Winter-Froemel, eds. Cognitive contact linguistics: placing usage, meaning and mind at the core of contact-induced variation and change, 1-20. (Cognitive Linguistics Research, 62.) Berlin: Mouton De Gruyter. https://doi.org/10.1515/9783110619430-001

\begin{abstract}
Kokkuvõte. Helin Kask: Ühilduda või mitte? Inglise adjektiivid eestiinglise kakskeelsetes blogides ja vlogides. Artiklis uuritakse, kas eestiinglise kakskeelsetes blogides ja vlogides ühilduvad inglise adjektiivid eesti substantiividega käändes ja arvus. Maatrikskeele raamistiku mudeli kohaselt eeldatakse, et inglise tüvele lisatakse vajalikud eesti käändelõpud ja muud tunnused, siiski ei ole see alati nii. Andmed pärinevad moe-, ilu- ja elustiiliblogidest ning -vlogidest, milles põhikeel on eesti keel, kuid milles kasutatakse ka inglise keelt. Kokku uuriti 84 nimisõnafraasi (inglise ADJ + eesti SUB), neist 35 juhul ühildus inglise adjektiiv eesti substantiiviga nii arvus kui ka käändes ning 46 juhul ei ühildunud, 3 juhul ei olnud võimalik ühildumist üheselt määrata. Analüüs näitas, et eesti substantiividega ühilduvad sellised ingliskeelsed adjektiivid, mis häälikulise ja silbistruktuuri poolest sarnanevad eesti muuttüüpide tüüpsõnadega. Mitteühildumise põhjused on astmevaheldus, erinevused kirjapildis ja häälduses, samuti informandi isiklikud eelistused.
\end{abstract}

Märksõnad: adjektiivid, ühildumine, keelekontaktid, blogid, vlogid, inglise keel, eesti keel 